\title{
Degradation of the Antibiotic Ceftriaxone by Fenton Oxidation Process and Compound Analysis
}

\author{
Hastheesudabye Puddoo, Rajesh Nithyanandam* and Thaothy Nguyenhuynh \\ School of Engineering, Taylor's University, Taylor's Lakeside Campus, \\ No. 1 Jalan Taylor's, 47500, Subang Jaya, Selangor, Malaysia \\ *Corresponding author: chemrajesh1982@gmail.com
}

Published online: 15 November 2017

To cite this article: Puddoo, H., Nithyanandam, R. \& Nguyenhuynh, T. (2017). Degradation of the antibiotic ceftriaxone by Fenton oxidation process and compound analysis. J. Phys. Sci., 28(3), 95-114, https://doi.org/10.21315/jps2017.28.3.7

To link to this article: https://doi.org/10.21315/jps2017.28.3.7

\begin{abstract}
Fenton oxidation process is used to degrade the recalcitrant pharmaceutical product ceftriaxone (CF), a commonly-used antibiotic in Malaysia. An effluent containing ceftriaxone antibiotic whose chemical oxygen demand (COD) and total suspended solids (TSS) was found to be $944 \mathrm{mg} \mathrm{l}^{-1}$ and $280 \mathrm{mg} \mathrm{l}^{-1}$ respectively. Physical and chemical treatment methods were employed to find the optimal concentration of Fenton reagent which was needed to degrade the antibiotic to a safe disposal level. Physical treatment included the variation in temperatures $\left(37^{\circ} \mathrm{C}, 42^{\circ} \mathrm{C}, 47^{\circ} \mathrm{C}\right.$ and $\left.50^{\circ} \mathrm{C}\right)$ and $\mathrm{pH}(2.6,5.2$, 6.1 and 10). The molar concentration of Fenton reagent was varied at 0.1, 0.2, 0.3, 0.35 and $0.4 \mathrm{M}$. The molar ratio of ferrous ions $\left(\mathrm{Fe}^{2+}\right)$ to hydrogen peroxide ions $\left(\mathrm{H}_{2} \mathrm{O}_{2}\right)$ in Fenton reagent was varied at 1:2, 1:4, 1:8 and 1:10. The optimum conditions for maximum reduction in $\mathrm{COD}$ level were at $\mathrm{pH}$ 2.6, $0.4 \mathrm{M}$ of Fenton reagent and $\mathrm{Fe}^{2+} / \mathrm{H}_{2} \mathrm{O}_{2}$ ratio of 1:8, reaching $84.6 \%$ reduction within 30 min of reaction. The experiment was carried out at ambient temperature $28^{\circ} \mathrm{C}$ and at atmospheric pressure. A further investigation ( $\mathrm{pH}$ and temperature variation) was made to deduce the percentage of reduction in terms of COD and TSS level that were obtained by the optimum sample. Findings reveal that a significant decrease of $76.5 \%$ was observed at $47^{\circ} \mathrm{C}$ and $\mathrm{pH}$ 5.2. Total suspended solid investigation reveals that a maximum reduction of $93 \%$ occurred at $0.4 M$ of Fenton reagent having the ratio of $\mathrm{Fe}^{2+} / \mathrm{H}_{2} \mathrm{O}_{2}$ of 1:2. Furthermore, 8 intermediates (5-thiazolecarboxylic acid, 5-[5-(methoxymethyl)-1,2-oxazol-3-yl]-4H-1,2,4-triazole-3,4-diamine, methanone bis [(methylthio)oxidoamino], 5-\{[2,6-dimethyl-4-(2-methyl-2-propanyl)benzyl]sulfonyl $\}$-1pentanol, benzene 5-(1,1-dimethylethyl)-2-[[(2-ethoxyethyl)sulfonyl]methyl]-1,3-dimethyl, $3 D$ 1-(ethylsulfonyl)-5-methoxy-6,6-dimethyl-4-heptanol, 3-\{[2,6-dimethyl-4-(2-methyl2-propanyl)benzyl]sulfonyl\}-1-propanol and 2R-3-[(S)-\{(1R)-1-[4-(2-methyl-2-propanyl)
\end{abstract}


phenyl]ethyl?sulfinyl]-1,2-propanediol were identified from the degradation products obtained by LC/MS analysis.

Keywords: Advanced oxidation processes, ceftriaxone antibiotic, $\mathrm{Fe}^{2+} / \mathrm{H}_{2} \mathrm{O}_{2}$ variation, LC-MS

\section{INTRODUCTION}

A large amount of antibiotic chemical is used as pharmaceutical products in the world reaching to an estimation of 100,000 to 200,000 tons per year. ${ }^{1}$ The purpose of antibiotics is to treat diseases in human and also to promote growth in the agricultural industry. ${ }^{2}$ Despite their vital importance in our daily life, antibiotics seem to raise a concern as a persistent water contaminant. ${ }^{3}$ The presence of the antibiotic has been reported around the world in rivers of Europe, water surfaces of America water streams of Australia and rivers of Asia. ${ }^{4-8,10}$

Antibiotic formulation effluents are well known for the difficulty of their elimination by traditional bio-treatment methods and their important contribution to environmental pollution is due to their fluctuating and recalcitrant nature. ${ }^{11}$ Until now, antibiotics have not yet been reported to be present in drinking water, only certain pharmaceuticals and diagnostics such as clofibric acid or amidotrizoic acid have been reported to date. ${ }^{11}$ Bacteria, fungi and microalgae are the organisms primarily affected by antibiotics, because antibiotics are designed to affect microorganisms. ${ }^{11}$ This will affect the ecosystem. However, hazards of the residual antibiotic in surface water (ceftriaxone) is not stated yet in the literature.

Besides the human health risks posed by the presence of antibiotic resistant bacteria in the environment, and the unwanted presence of antibiotics in water bodies, concern for the ecological fate and environmental threat of antibiotics in the aquatic milieu is becoming a global phenomenon. ${ }^{11}$ In the determination of ceftriaxone in plasma and urine by high-performance liquid chromatography, a study proved that drug ceftriaxone stability during sample storage, sample pretreatment and chromatography showed no degradation of ceftriaxone. ${ }^{12}$ This is one of the evidences that the compound is recalcitrant. Until now the presence of ceftriazone in water bodies in Malaysia has not been found despite being prescribed by doctors mostly. However, there are evidences showing that this type of antibiotics is most dangerous threat to water bodies since this type of contaminants has been present in water bodies in Nigeria. ${ }^{13}$ This study is carried out taking perspective from global point of view. 
Antibiotics, once administered, are metabolised and excreted through urine and faeces which eventually reach sewage. The sewage water requires to be treated in wastewater treatment plants (WWTP). However, it was noticed that the antibiotic compounds were still present after treatment confirming the inability of conventional WWTP to degrade recalcitrant materials. Similarly, the effluent wastewater from pharmaceutical manufacturing industries still contains antibiotic traces after treatment. ${ }^{14}$

Since the conventional wastewater treatment does not fully remove recalcitrant pharmaceutics, an approach to an additional advanced treatment technology is required. There are different advanced technologies which have been studied recently for the purpose of disintegrating non-biodegradable products. Those technologies are chemical oxidation using ozone and ozone/hydrogen peroxide, activated carbon as sorption processes and membrane filtration such as nanofiltration and reverse osmosis. ${ }^{15-18}$ The limitations of treating further the concentrate from membrane filtration and sorption processes drive the interest towards further exploring and optimising chemical oxidation process. ${ }^{19}$

Advanced oxidation processes (AOPs) are based on the generation of free hydroxyl radicals $(\mathrm{OH})$. Free hydroxyl radicals are highly reactive due to their unstable state in the configuration of energy shell, and non-selective oxidising agents. The radicals are able to degrade organic pollutants by hydrogen atom abstraction reaction, followed by electron transfer or electrophilic addition to $\pi$ systems. ${ }^{20}$ There are several AOPs namely $\mathrm{UV} / \mathrm{O}_{3}, \mathrm{O}_{3}$ and $\mathrm{O}_{3} \mathrm{H}_{2} \mathrm{O}_{2}$ which exist. Among these AOPs, an effective AOP is Fenton process. ${ }^{19}$

Fenton reagent consists of a mixture of ferrous ions $\left(\mathrm{Fe}^{2+}\right)$ and hydrogen peroxide $\left(\mathrm{H}_{2} \mathrm{O}_{2}\right)$. Different results in terms of reduction in organic content and toxicity were obtained by varying the molar ratio of ferrous to hydrogen peroxide in the Fenton reagent. ${ }^{21}$ Other parameters such as $\mathrm{pH}$ and temperature also affect the efficiency of the process. ${ }^{19}$ An analytical way to compare results is to verify the chemical oxygen demand (COD) level and total suspended solids (TSS) level before the oxidation process and after the treatment.

Ceftriaxone, as shown in Figure 1, is an antibiotic used for bacterial infection such as pneumonia, ear infections and skin infection. Ceftriaxone is mostly used when organisms are resistant to other commonly used antibiotics such as amoxicillin and penicillin. Ceftriaxone is available in tablet form as well as solvent form for injection. The most common way to administer ceftriaxone into human beings is by injection; intravenous or intramuscular. ${ }^{22}$ 


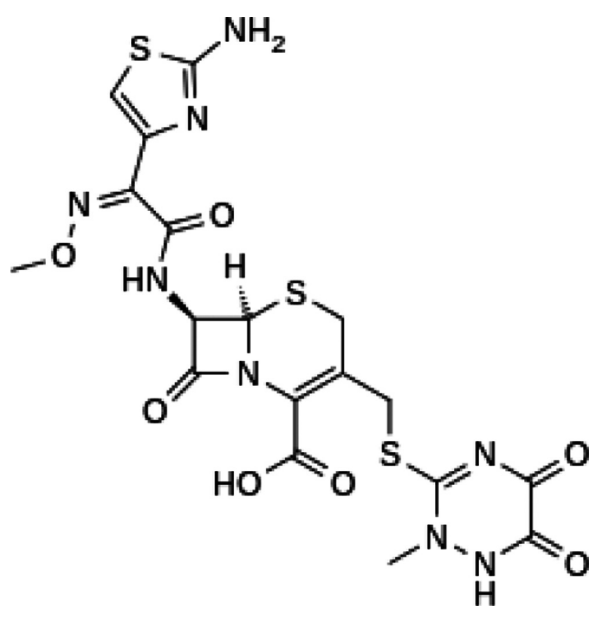

Figure 1: Skeletal structure of ceftriaxone antibiotic.

Antibiotic prescribing rates are high in both public and private primary care settings in Malaysia, especially in the latter. The antibiotic groups prescribed in descending order of preference were: penicillins, cephalosporins, macrolides, quinolones and tetracyclines in Malaysia. ${ }^{23}$ Ceftriaxone is classified under cephalosporins group. According to Sulong et al., ceftriaxone is a widely prescribed antibiotic by the physicians in Tuanku Mizan Armed Forces Hospital (TMAFH) in Malaysia. ${ }^{24}$ It has become the most frequently prescribed antibiotic in the hospital, recording a distinctive high number of prescription orders. ${ }^{24}$ During production this compound may prevail in pharmaceutical wastewater due to high demand.

To carry out this research, an artificial effluent was obtained. It was also found that only a few studies were carried out on the Fenton effect of oxidation on ceftriaxone despite its common use in Malaysia. There is no literature on degradation of ceftriaxone by Fenton process, nor any publication on the intermediates produced by AOP degradation of the antibiotic. ${ }^{25}$ Therefore, ceftriaxone was chosen to be studied to close this research gap. Contribution to the body of knowledge includes the identification of intermediates formed during degradation of ceftriaxone by AOP.

The main objective of this research is to find out the degradation efficiency of ceftriaxone antibiotic using Fenton oxidation process by varying concentrations and molar ratios of $\mathrm{Fe}^{2+} \mathrm{H}_{2} \mathrm{O}_{2}$ of Fenton reagent. A further investigation is made on that particular optimum ratio which has been found, to study the effect of temperature and $\mathrm{pH}$ on the degradation in terms of COD/TSS level reduction. Finally, LC/MS technology is used to determine the degradation products obtained in the treated sample. 


\section{EXPERIMENTAL}

\subsection{Chemicals and Antibiotic}

Ferrous sulfate heptahydrate $\left(\mathrm{FeSO}_{4} \cdot 7 \mathrm{H}_{2} \mathrm{O}\right)$ and hydrogen peroxide $(30 \% \mathrm{w} / \mathrm{w})$ were purchased from Systerm, Malaysia. Sulfuric acid 98\% Grade AR and sodium hydroxide pellets were purchased from Schmidt Chemical, Malaysia. High performance liquid chromatography (HPLC) grade methanol (99.9\%) was obtained from Merck. A small amount of ceftriaxone sodium (1g) was obtained from Klinik Kapar, Kuala Selangor, Malaysia (Stravencon Ltd.).

\subsection{Analytical Methods}

\subsection{1 pH measurement}

The $\mathrm{pH}$ of each sample was measured using an electronic $\mathrm{pH}$ meter with $\mathrm{pH}$ probe (Hanna GLP, United States).

\subsubsection{Chemical oxygen demand}

Chemical oxygen demand (COD, $\mathrm{mg}^{-1}$ ) was measured using Standard Method 410 (Titrimetric, Mid-level)and digestion solution of dichromate. ${ }^{26}$ Concentrated sulphuric acid was used as a strong oxidising agent. Ferrous ammonium sulphate (FAS) solution was used as standard stock to titrate against the digested sample. The digestion solution and the treated sample were kept under closed reflux at $150^{\circ} \mathrm{C}$ for $2 \mathrm{~h}$. Ferroin solution was used as indicator.

\subsubsection{Total suspended solids}

Total Suspended Solids (TSS, $\mathrm{mg}^{-1}$ ) was measured using Standard Method 2540D. ${ }^{27}$ 934-AH RTU glass microfibre filters were used. The filter paper was washed with Milli-Q ultrapure water to remove any impurities. The filter paper was placed on an aluminum dish and was oven dried for $2 \mathrm{~h}$ at $105^{\circ} \mathrm{C}$. The filter was then weighed using an analytical balance. The filter paper was then placed onto a vacuum filter set-up. An amount of $10 \mathrm{ml}$ of the water sample was pipetted through the filter paper. The vacuum suction set-up fastened the filtration process. The filter paper containing the suspended solids from the degraded antibiotic was oven dried for $2 \mathrm{~h}$ at $105^{\circ} \mathrm{C}$. The filter paper was weighed again in duplicate and TSS value can be calculated. 


\subsubsection{Qualitative analysis}

LC/MS Q-TOF was used to carry out the analysis of the degradation products. The equipment was an Agilent Series Model G6550A. The sample was quenched with HPLC grade methanol. The quenched sample was then filtered through a $0.45 \mu \mathrm{m}$ membrane. The analysis was carried out in negative ionisation mode, using HPLC (Agilent series 1100) equipped with a $3 \times 150 \mathrm{~mm} \mathrm{C18}$ Column, $5 \mu \mathrm{m}$ particle size (Zorbax-Agilent Technologies). The mobile phases $\mathrm{A}$ and $\mathrm{B}$ were acetonitrile and water with $0.1 \%$ formic acid, respectively, at a flow rate of $0.4 \mathrm{ml}$ per min. The injection volume was $20 \mu \mathrm{l}$. A linear gradient progressed from $10 \%$ A to $100 \% \mathrm{~A}$ in $30 \mathrm{~min}$ and held for $3 \mathrm{~min}$. A retention time of ceftriaxone was between 27.1 and 28.9 min with a detection limit of $5 \mathrm{mg} \mathrm{l}^{-1}$. The HPLC system was connected to an Agilent MSD time-of-flight mass spectrometer with an electrospray interface operating under the following conditions: capillary, $4000 \mathrm{~V}$; nebulizer, $40 \mathrm{psi}$; drying gas, $7.01 \mathrm{~min}^{-1}$; gas temperature, $300^{\circ} \mathrm{C}$; skimmer voltage, $60 \mathrm{~V}$; octapole dc1, 36.5 V; octapole rf, $250 \mathrm{~V}$; fragmentor, $190 \mathrm{~V}$.

ChemSpider software was used to identify the structural formula of the intermediates which occurred within a matching range of $90 \%$ to $100 \%{ }^{28}$

\subsubsection{Statistical analysis}

All the experiments were carried out in triplicate and IBM SPSS 22.0 software program was used to perform statistical analysis. Analysis of variance (ANOVA) was performed by paired sample t-test. A t-test analysis was used because the number of sample is less than 100. A significant change in the variance of COD/ TSS level of pre-treated sample and tested sample was observed. Mean differences were considered significant at the $p<0.05$.

\subsection{Synthetic Effluent}

Ceftriaxone sodium was not purified further before use. $500 \mathrm{mg}$ of ceftriaxone sodium was measured and diluted in $1000 \mathrm{ml}$ of distilled water to prepare a pharmaceutical effluent concentration of $500 \mathrm{mg} \mathrm{l}^{-1}$. The room temperature and $\mathrm{pH}$ of solution were recorded immediately. The room temperature showed $28^{\circ} \mathrm{C}$ and the pharmaceutical effluent has a $\mathrm{pH}$ 5.9. The pharmaceutical effluent was kept refrigerated at $4{ }^{\circ} \mathrm{C}$ and covered by aluminum foil in the dark to avoid any degradation. 


\subsection{Fenton Oxidation Process}

Fenton reagent is the addition of ferrous sulphate to hydrogen peroxide. Initially ferrous sulphate was added to pharmaceutical effluent and mixed thoroughly. Later to the mixture, $\mathrm{H}_{2} \mathrm{O}_{2}$ was added. The reaction was extremely exothermic and reactive. The pharmaceutical effluent was treated with different molar concentrations of Fenton reagent at different molar ratio of 1:2, 1:4, 1:8 and 1:10.

An amount of $20 \mathrm{ml}$ of pharmaceutical effluent was poured into four $250 \mathrm{ml}$ beakers. The $\mathrm{pH}$ of the effluent was adjusted by adding a few drops of $0.05 \mathrm{M}$ of sulfuric acid to bring the $\mathrm{pH}$ between 2 to $3 .{ }^{29}$ For 0.1 molar ratio of Fenton reagent, $1: 2$ ratio of Ferrous to hydrogen peroxide, $6.2 \mathrm{~g}$ of ferrous sulphate was added to pharmaceutical effluent. The mixture was mixed thoroughly. Later, $12.5 \mathrm{ml}$ of hydrogen peroxide was added to the mixture. During this step, foam formation occurred and the reaction was exothermic.

Similarly, different ratios $(1: 4,1: 8$ and 1:10) of ferrous to hydrogen peroxide were added to $20 \mathrm{ml}$ of pharmaceutical effluent. The experiment was also repeated for different concentrations of Fenton reagent $(0.2,0.3,0.35$ and $0.4 \mathrm{M})$ and different ratios $(1: 4,1: 8$ and 1:10) of ferrous to hydrogen peroxide.

\subsection{Variation of $\mathrm{pH}$ and Temperature}

First, $100 \mathrm{ml}$ of the pharmaceutical effluent was taken. A few drops of diluted sulfuric acid $(0.001 \mathrm{M})$ was added to adjust the $\mathrm{pH}$ to $5.2 .20 \mathrm{ml}$ of the untreated sample was distributed into 4 different $50 \mathrm{ml}$ beakers and heated up to $37^{\circ} \mathrm{C}, 42^{\circ} \mathrm{C}$, $47^{\circ} \mathrm{C}$ and $50^{\circ} \mathrm{C}$ respectively using a hot plate magnetic stirrer for $45 \mathrm{~min}$. COD $\left(\mathrm{mg} \mathrm{l}^{-1}\right)$ level was tested for each sample after treatment with Fenton reagent.

From the $100 \mathrm{ml}$ of the pharmaceutical effluent taken, $20 \mathrm{ml}$ of pharmaceutical effluent was poured into 4 different flasks each. Effluent $\mathrm{pH}$ was varied to 2.6, 5.2, 6.1 and 10.1 by the addition of sulfuric acid or sodium hydroxide solution. COD $\left(\mathrm{mg} \mathrm{l}^{-1}\right)$ level was tested for each sample after treatment with Fenton reagent.

\section{RESULTS AND DISCUSSION}

\subsection{COD Variation for Different Molar Ratio of Fenton Reagent of $\mathrm{Fe}^{2+} / \mathrm{H}_{2} \mathrm{O}_{2}$}

The chemical treatment results for COD $\left(\mathrm{mg} \mathrm{l}^{-1}\right)$ obtained from the treated pharmaceutical effluent are displayed in Figure 2. At $0.1 \mathrm{M}$ of Fenton reagent, a gradual decrease in COD $\left(\mathrm{mg} \mathrm{l}^{-1}\right)$ level was observed as the molar ratio of $\mathrm{Fe}^{2+} / \mathrm{H}_{2} \mathrm{O}_{2}$ 
increased. This indicates that a higher amount of hydrogen peroxide generated a higher number of hydroxyl radicals and thus, more carbon atoms may be oxidised. The percentage reduction of COD $\left(\mathrm{mg} \mathrm{l}^{-1}\right)$ level varied from a maximum of $64.6 \%$ (displayed at a $\mathrm{Fe}^{2}+/ \mathrm{H}_{2} \mathrm{O}_{2}$ of $1: 10$ ) to a minimum of $56.9 \%$ (displayed at $\mathrm{Fe}^{2+} / \mathrm{H}_{2} \mathrm{O}_{2}$ of $1: 2$ ) within $30 \mathrm{~min}$ of degradation reaction. The efficiency of the oxidation process is not desirable because approximately $40 \%$ of the recalcitrant antibiotic, i.e., organic compound was still present in the treated sample. The organic compounds which did not degrade may be accounted by the overall insufficient supply of hydroxyl radicals. ${ }^{19}$

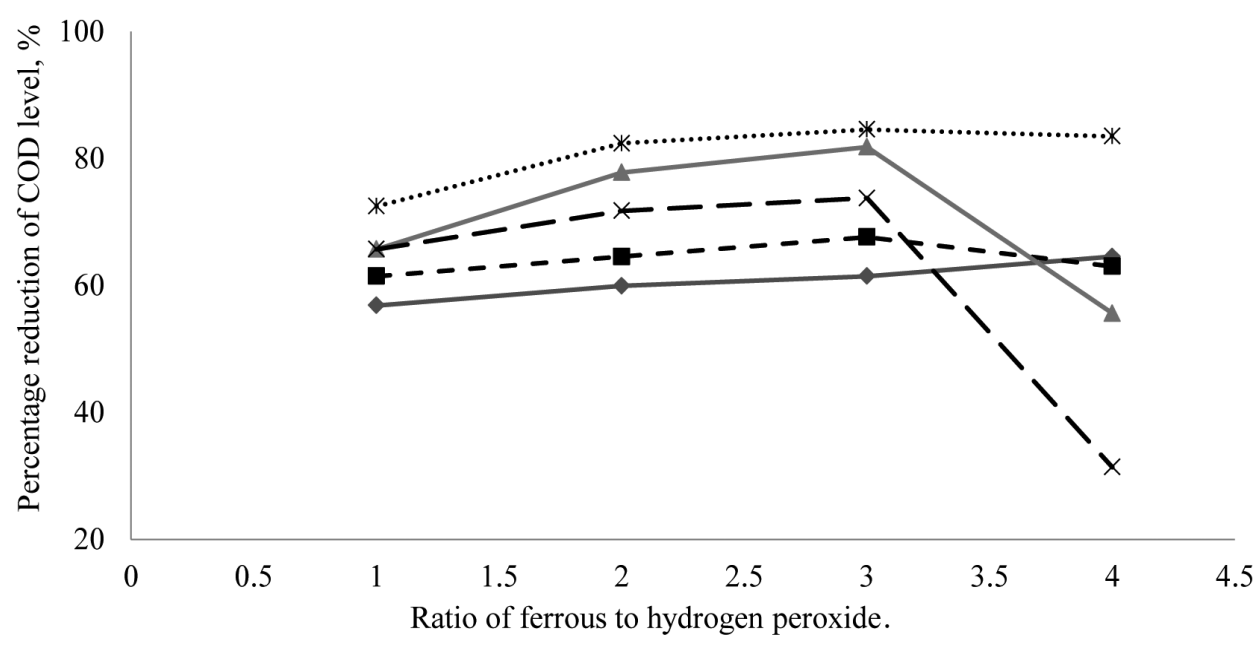

$\begin{array}{llr}\longrightarrow 0.1 \mathrm{M} \text { of Fenton Reagent } & -\mathbf{-}-0.2 \mathrm{M} \text { of Fenton Reagent } & \underline{\text { Legend }} \\ 1=1: 2 \\ 2=1: 4 \\ 3=1: 8 \\ 4=1: 10\end{array}$

Figure 2: Percentage COD reduction for different variation in ratio of $\mathrm{Fe}_{2}+/ \mathrm{H}_{2} \mathrm{O}_{2}$ at molar concentration $0.1 \mathrm{M}, 0.2 \mathrm{M}, 0.3 \mathrm{M}, 0.35 \mathrm{M}$ and $0.4 \mathrm{M}$.

At $0.2 \mathrm{M}$ of Fenton reagent, degradation efficiency is higher than $0.1 \mathrm{M}$ with a maximum degradation $67.4 \%$ (displayed at $\mathrm{Fe}^{2+} / \mathrm{H}_{2} \mathrm{O}_{2}$ ratio of $1: 8$ ). The minimum decrease in COD $\left(\mathrm{mg} \mathrm{l}^{-1}\right)$ of $61.5 \%$ is observed at a ferrous to hydrogen peroxide ratio of 1:2. The degradation retention time was maintained at $30 \mathrm{~min}$. This implies that a higher concentration of Fenton reagent leads to a higher decrease in COD $\left(\mathrm{mg} \mathrm{l}^{-1}\right)$ level of treated sample. The oxidation efficiency is not desirable as a significant amount of approximately $40 \%$ of recalcitrant products is still present in the treated sample and requires more time for degradation process. At $\mathrm{Fe}^{2+}$ $\mathrm{H}_{2} \mathrm{O}_{2}$ of $1: 10$, the decrease in COD $\left(\mathrm{mg} \mathrm{l}^{-1}\right)$ level is $63 \%$ which is lower than the 
degradation efficiency observed at $\mathrm{Fe}^{2+} / \mathrm{H}_{2} \mathrm{O}_{2}$ of $1: 4$ and 1:8. This slight increase in COD level is accounted by a phenomenon which happens when a sudden higher amount of hydroxyl radical is generated within a short period of time causing the diminution of dissolved oxygen. ${ }^{19}$

At higher molar concentration of $0.3 \mathrm{M}$ of Fenton reagent, maximum reduction in COD is as high as $81.8 \%$. 1:2 molar ratio of $\mathrm{Fe}^{2+} / \mathrm{H}_{2} \mathrm{O}_{2}$ shows the lowest COD reduction of $65.7 \%$, which is still more efficient than previous 0.1 and $0.2 \mathrm{M}$ concentration of Fenton reagent. At $\mathrm{Fe}^{2+} \mathrm{H}_{2} \mathrm{O}_{2}$ of 1:10, the degradation reaction was less compared to all other samples. The excessive amount of hydrogen peroxide interferes in the experiment by reacting with $\cdot \mathrm{OH}$ and hence, reducing the efficiency of the treatment. ${ }^{30}$ Similar results are observed during Fenton reagent study on the pharmaceutical sludge by Nithyanandam et al. ${ }^{19}$

At $0.35 \mathrm{M}$ concentration of Fenton reagent, maximum COD level reduction of $73.7 \%$ is observed. It was observed that $0.35 \mathrm{M}$ concentration shows a lower efficiency than $0.3 \mathrm{M}$ concentration. This may be related to the reaction kinetics during the degradation process. ${ }^{19,31}$ The minimum reduction is $31.4 \%$ at molar ratio of $\mathrm{Fe}^{2+} / \mathrm{H}_{2} \mathrm{O}_{2}$ of $1: 10$.

The most efficient and promising efficiency occurs at $0.4 \mathrm{M}$. All the samples showed high reduction in a range of $72 \%$ to $84 \%$ within 30 min of reaction. The highest peak of $84.6 \%$ was recorded at the molar ratio of $\mathrm{Fe}^{2+} / \mathrm{H}_{2} \mathrm{O}_{2}$ of $1: 8$. Since that particular sample shows the maximum percentage of reduction and hence, high efficiency, it is considered as the optimum $\mathrm{Fe}^{2+} / \mathrm{H}_{2} \mathrm{O}_{2}$ ratio and conditions for degradation of the antibiotic ceftriaxone. A pH of 2-3 and ambient temperature of $28^{\circ} \mathrm{C}$ are maintained. It is observed that there is not much difference between the efficiency of $0.3 \mathrm{M}$ and $0.4 \mathrm{M}$ of Fenton reagent. Study done by Zanta and Martinez-Huitle shows that threshold values for optimisation of Fenton reaction are around $\mathrm{pH} 2-3$ and molar ratio $\mathrm{Fe}^{2+} / \mathrm{H}_{2} \mathrm{O}_{2}$ greater than 1:5, a reagent concentration of 0.3 and above. ${ }^{32}$

The antibiotic has a promising potential to reach mineralisation level if the hydroxyl radicals are allowed to react for a longer period of time. ${ }^{33}$ Mineralisation is the complete degradation of the organic compound into water $\left(\mathrm{H}_{2} \mathrm{O}\right)$ and carbon dioxide $\left(\mathrm{CO}_{2}\right)$. From the findings, so far it seems feasible to implement this oxidation process after secondary treatment in pharmaceutical industrial wastewater plants. However, the Fenton reaction works in an acidic environment of $\mathrm{pH} 2-3$. It is well known that WWTPs do not operate at such low $\mathrm{pH}$. Hence, a method to restore the appropriate working $\mathrm{pH}$ of WWTP should be further studied, optimised and to be employed. 


\subsection{TSS Variation for Different Molar Ratios of Fenton Reagent of $\mathrm{Fe}^{2+} / \mathrm{H}_{2} \mathrm{O}_{2}$}

Initial amount of TSS was found to be $280 \mathrm{mg}^{-1}$. The highest efficiency of TSS is $93 \%$ at $0.4 \mathrm{M}$ of Fenton reagent and molar ratio of $\mathrm{Fe}^{2+} / \mathrm{H}_{2} \mathrm{O}_{2}$ of $1: 2$ as shown in Figure 3. The lowest efficiency is only $16 \%$ at Fenton reagent concentration of $0.35 \mathrm{M}$ and molar ratio of $\mathrm{Fe}^{2+} / \mathrm{H}_{2} \mathrm{O}_{2}$ of $1: 8$. A similar concentration of $0.35 \mathrm{M}$ did not prove to be efficient as shown by COD variation charts. The same reason might be because of the reaction kinetics. It can be seen that the molar ratio of $\mathrm{Fe}^{2+} / \mathrm{H}_{2} \mathrm{O}_{2}$ directly affects the amount of TSS $\left(\mathrm{mg} \mathrm{l}^{-1}\right)$ in the treated samples. The ratios which give the lowest TSS $\left(\mathrm{mg} \mathrm{l}^{-1}\right)$ is at $1: 2$ and $1: 8 .{ }^{19}$ The hydroxyl radical attack indicates that bonds do not break in an orderly manner but rather depending on concentration of radicals present during the reaction and the kinetic rate of each reaction. ${ }^{33}$

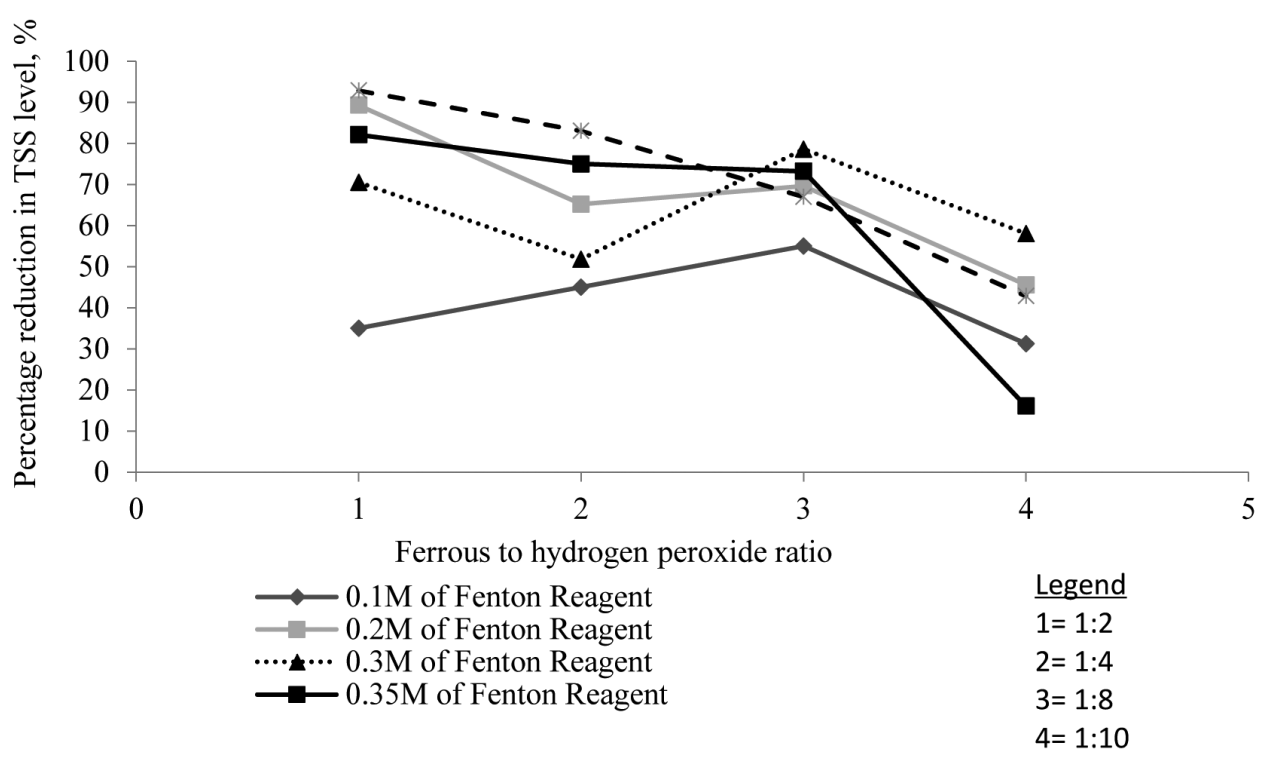

Figure 3: Percentage TSS reduction for different variation in ratio of $\mathrm{Fe}_{2}+/ \mathrm{H}_{2} \mathrm{O}_{2}$ at molar concentration $0.1 \mathrm{M}, 0.2 \mathrm{M}, 0.3 \mathrm{M}, 0.35 \mathrm{M}$ and $0.4 \mathrm{M}$.

In the Fenton system, the reaction between ferrous ions and the hydrogen peroxide which produces hydroxyl radicals and ferric ions, has a high rate constant $\left(k=631 \mathrm{~mol}^{-1} \mathrm{~s}^{-1}\right)$. However, $\mathrm{Fe}(\mathrm{II})$ regeneration from $\mathrm{Fe}(\mathrm{III})$ and the $\mathrm{H}_{2} \mathrm{O}_{2}$ reaction, is much slower $\left(k=3.1 \times 10^{-3} \mathrm{l} \mathrm{mol}^{-1} \mathrm{~s}^{-1}\right){ }^{34}$ Hence higher radical concentration has the capability to reduce TSS at a faster rate, however because of addition of Ferrous sulphate amount of sludge will be increased too. This can be removed by gravity separation. 
A high reduction in TSS level indicates that the organic compounds found in the antibiotic effluent have been reduced in terms of their molecular structures. ${ }^{33}$ As the radicals attack the bonds in between the carbon and hydrogen atoms, some carbon atoms' bonds are broken from bigger molecular compound of the antibiotic. This results into smaller functional groups like thiozole and carboxylic acid groups. ${ }^{35}$

\subsection{COD Variation by Varying $\mathrm{pH}$ and Temperature}

From the result shown in Figure 4, it can be deduced that the Fenton reagent works best within a $\mathrm{pH}$ of $2-3$ as previously reviewed from the literature. ${ }^{19}$ Generation of hydroxyl radical depends largely on the $\mathrm{pH}$ value of the solution in which the radicals are generated. As the $\mathrm{pH}$ increases to more than 4 , lower number of radicals are formed and thus, degradation efficiency is reduced. Less radicals being formed may be due to the fact that there is a decrease in dissolved iron. ${ }^{19}$ Maximum reduction in COD was, however, recorded at $\mathrm{pH} 5.2$ and temperature of $47^{\circ} \mathrm{C}$. $\mathrm{pH} 6.1$ shows that COD level can be reduced furthermore compared to other $\mathrm{pH}$ values. An increase in temperature does not seem to affect the process significantly.

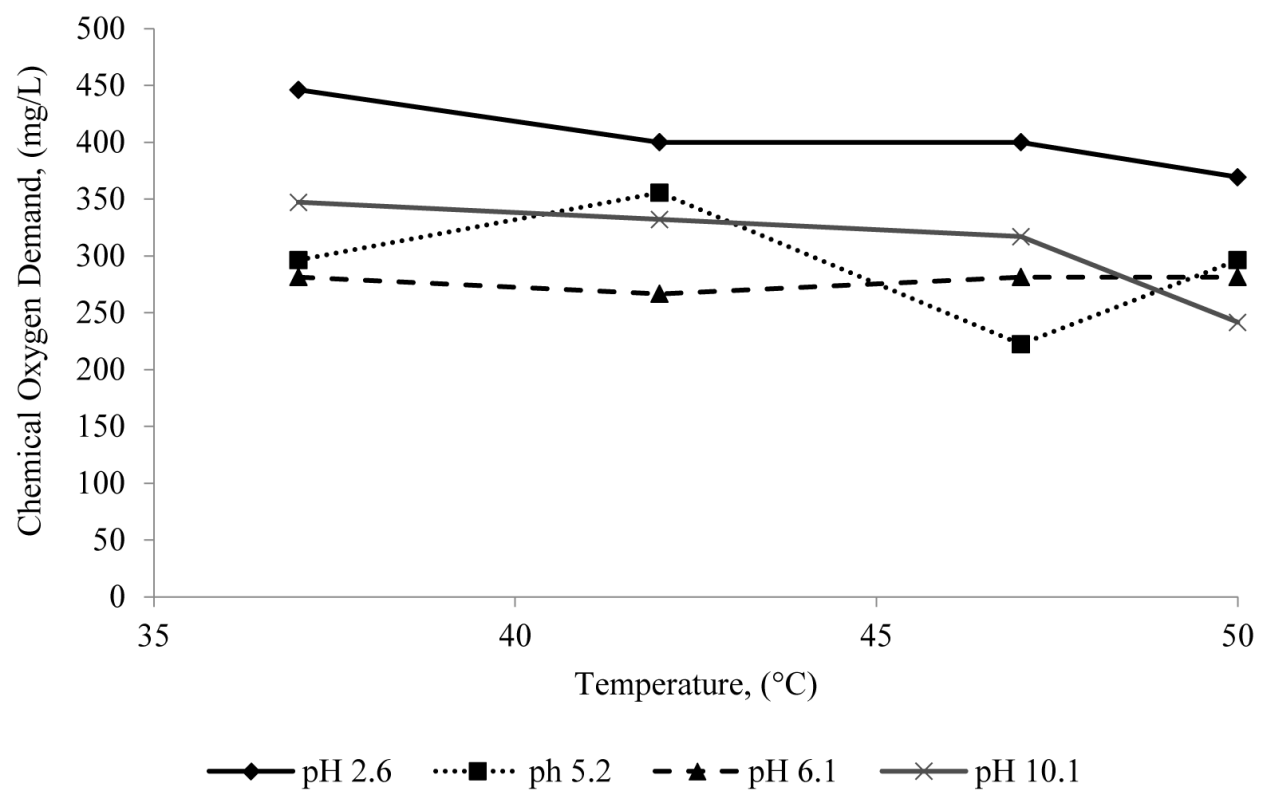

Figure 4: $\mathrm{COD}\left(\mathrm{mg} \mathrm{l}^{-1}\right)$ variation by varying the $\mathrm{pH}$ and Temperature $\left(37^{\circ} \mathrm{C}, 42^{\circ} \mathrm{C}, 47^{\circ} \mathrm{C}\right.$ and $\left.50^{\circ} \mathrm{C}\right)$.

A considerate reduction in antibiotic component has been achieved. However, mineralisation of the ceftriaxone antibiotic results into water and carbon dioxide. Carbon dioxide is not a water pollutant but is a greenhouse gas. It is well known 
that greenhouse gases are causing a major climate change. By solving the problem of antibiotics present in water streams, the method should not raise other issues for the environment. Further procedures should be employed such as carbon capture technologies for reusing carbon dioxide more efficiently rather than just releasing into the air. Simple procedure such as passing the gas through calcium carbonate can be explored. The procedure also uses acidic conditions to operate. Neutralisation should be done after treatment by addition of alkali-based products such as sodium hydroxide. By using the Fenton reagent, some precipitation of $\mathrm{Fe}^{3+}$ will occur after $2 \mathrm{~h}$ of treatment. The precipitation may be removed by the addition of sodium hydroxide which will result into $\mathrm{Fe}(\mathrm{OH})$ salt. ${ }^{19}$

\subsection{Statistical Analysis Using SPSS 22.0}

Figure 5(a) shows the statistical results obtained from SPSS software 22.0. From the result of statistical test (paired samples $t$-test), the mean difference in COD at $t=36.44$ and $p$ value is less than $5 \%$, it can be concluded that a null hypothesis can be rejected. The null hypothesis states that the mean of the COD level before treatment and after treatment is the same. Clearly, there is a significant difference in the mean of COD level before the treatment and after the Fenton process treatment. For TSS, the null hypothesis is rejected because the results obtained at $t=10.72$ and $p<5 \%$. Therefore, the reduction in TSS level after treatment was significantly different. All testing was carried out at a 95\% confidence level.

\begin{tabular}{|c|c|c|c|c|c|c|c|c|}
\hline \multicolumn{9}{|c|}{ Paired Samples Test } \\
\hline & \multicolumn{5}{|c|}{ Paired Differences } & \multirow[b]{3}{*}{$t$} & \multirow[b]{3}{*}{ df } & \multirow[b]{3}{*}{ Sig. (2-tailed) } \\
\hline & \multirow[b]{2}{*}{ Mean } & \multirow[b]{2}{*}{ Std. Deviation } & \multirow{2}{*}{$\begin{array}{c}\text { Std. Error } \\
\text { Mean }\end{array}$} & \multicolumn{2}{|c|}{$\begin{array}{l}\text { 95\% Confidence Interval of the } \\
\text { Difference }\end{array}$} & & & \\
\hline & & & & Lower & Upper & & & \\
\hline preCOD-COD & 677.88000 & 83.18510 & 18.60075 & 638.94817 & 716.81183 & 36.444 & 19 & .000 \\
\hline preTSS-TSS & 165.47500 & 69.02488 & 15.43443 & 133.17036 & 197.77964 & 10.721 & 19 & .000 \\
\hline
\end{tabular}

a) T-test applied for samples before and after treatment.

\begin{tabular}{|ll|r|r|r|r|r|}
\hline \multicolumn{1}{|c|}{ ANOVA } \\
\hline & \multicolumn{1}{|c|}{$\begin{array}{c}\text { Sum of } \\
\text { Squares }\end{array}$} & \multicolumn{1}{c|}{ df } & Mean Square & F & Sig. \\
\hline COD & Between Groups & 56133.322 & 3 & 18711.107 & 1.483 & .257 \\
& Within Groups & 201917.736 & 16 & 12619.859 & & \\
& Total & 258051.058 & 19 & & & \\
\hline TSS & Between Groups & 29150.238 & 3 & 9716.746 & 2.533 & .094 \\
& Within Groups & 61374.000 & 16 & 3835.875 & & \\
& Total & 90524.238 & 19 & & & \\
\hline
\end{tabular}

b) ANOVA test for samples with variation of COD and TSS.

Figure 5: Statistical analysis results. 
Variation in the ratio of $\mathrm{Fe}^{2+} \mathrm{H}_{2} \mathrm{O}_{2}$ at different molar concentration from 0.1 to 0.4 (referring to Figure 3) resulted in an insignificant different in the percentage reduction in TSS level since the statistical analysis result has $F=1.483$, $p=0.257>5 \%$ shown in Figure 5(b). With a range of $\mathrm{pH}$ varying from 2.6 to 10.1 and temperature from $37^{\circ} \mathrm{C}$ to $50^{\circ} \mathrm{C}$ (referring to Figure 4), this is no significant different in the level of COD as the statistical result in $F=2.533, p=0.094>5 \%$.

\subsection{Compound Analysis of Degradation Process}

Figures 6 and 7, and Table 1 represent 8 main compounds that have been identified from the 54 components (not shown) detected from the chromatogram graph obtained in Liquid Chromatography/Mass Spectrometry Quadrupole Time-ofFlight (LC/MS Q TOF) analysis.

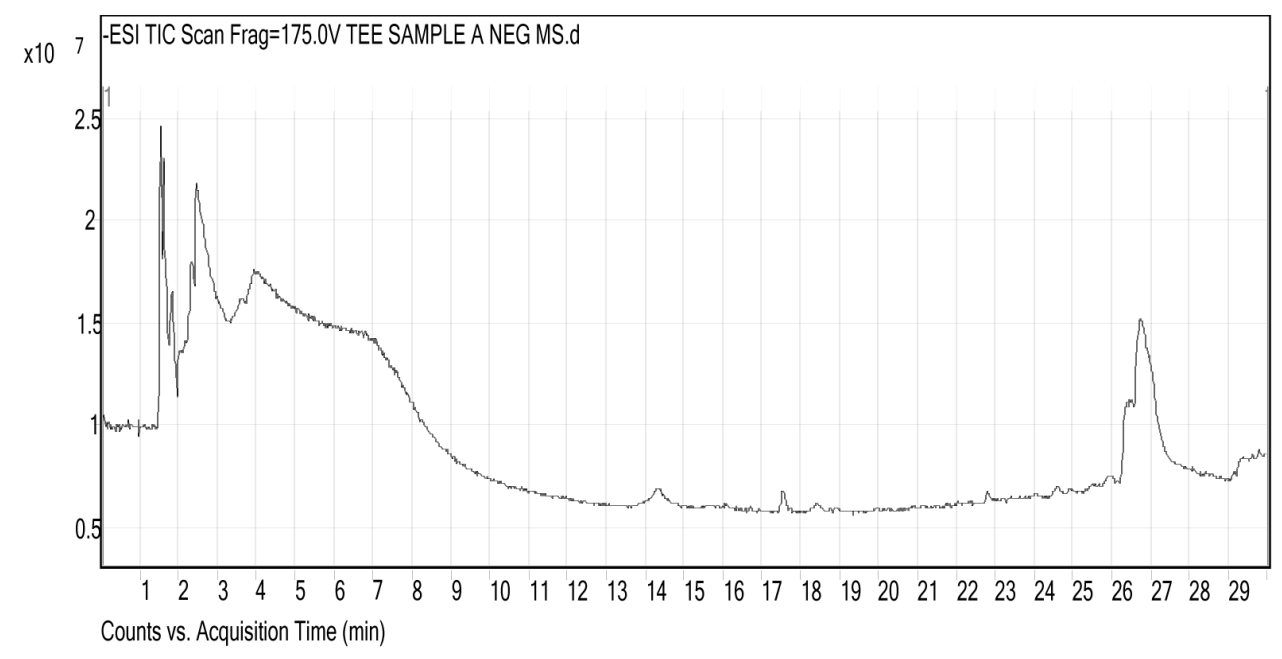

Figure 6: Chromatogram A of LC MS analysis.

The degradation of cephalosporin is highly dependent on the side chain $\mathrm{C}_{7}$ and the $\mathrm{C}_{3}$ atoms. The leaving group at $\mathrm{C}_{3}$ facilitates the expulsion of 3'-substituent by concerted event due to hydrolysis of $\mathrm{C}-\mathrm{N}$ bond of $\beta$-lactam nucleus. As can be seen from Table 1, there is no beta-lactam ring present even in the highest carbon containing molecule $\mathrm{C}_{4}$ identified (5-\{[2,6-dimethyl-4-(2-methyl-2-propanyl) benzyl] sulfonyl $\}-1$-pentanol) at peak mass of 326 and $\mathrm{C}_{5}$ molecule (identified as benzene, 5-(1,1-dimethylethyl)-2-[[(2-ethoxyethyl) sulfonyl] methyl]-1,3dimethyl) giving clue that the beta-lactam ring got attacked in the first stages of degradation. Normally, authors point out that, hydroxylation takes places at early stage of degradation. ${ }^{36}$ 


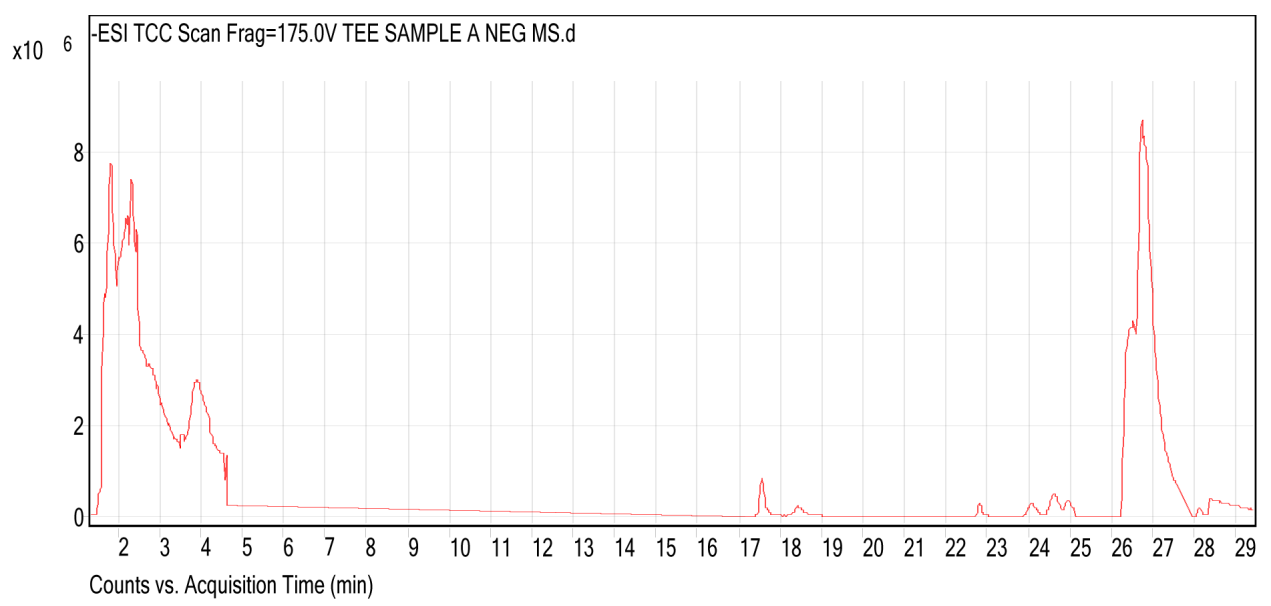

Figure 7: Chromatogram B of LC MS analysis.

Table 1: Identification of degradation products from LC/MS Q TOF analysis.

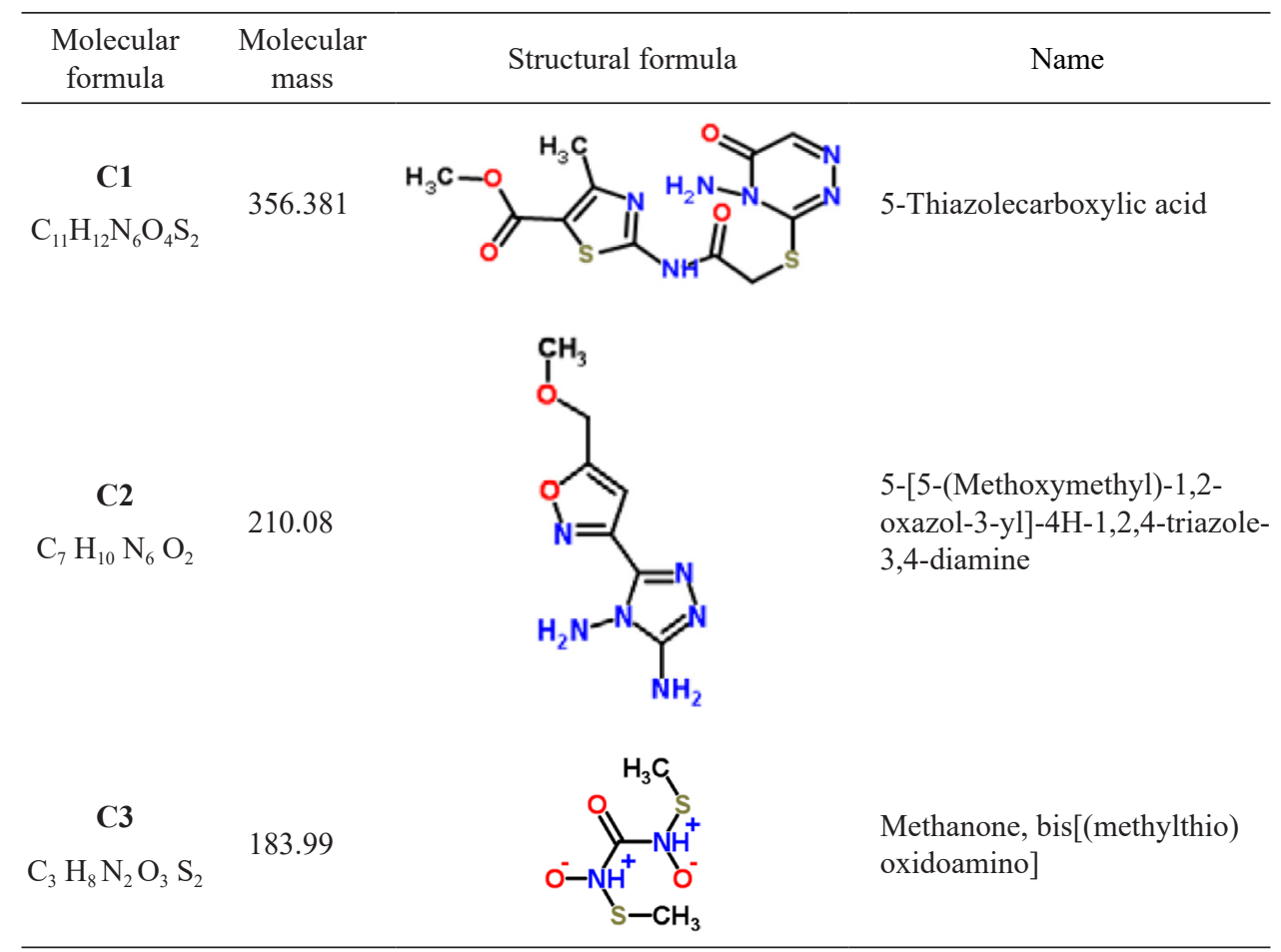


Table 1 (Continued)

\begin{tabular}{|c|c|c|c|}
\hline $\begin{array}{l}\text { Molecular } \\
\text { formula }\end{array}$ & $\begin{array}{c}\text { Molecular } \\
\text { mass }\end{array}$ & Structural formula & Name \\
\hline $\begin{array}{c}\mathbf{C 4} \\
\mathrm{C}_{18} \mathrm{H}_{30} \mathrm{O}_{3} \mathrm{~S}\end{array}$ & 326.494 & & $\begin{array}{l}\text { 5-\{[2,6-Dimethyl-4-(2-methyl- } \\
\text { 2-propanyl)benzyl]sulfonyl }\} \text { - } \\
\text { 1-pentanol }\end{array}$ \\
\hline $\begin{array}{c}\text { C5 } \\
\mathrm{C}_{17} \mathrm{H}_{28} \mathrm{O}_{3} \mathrm{~S}\end{array}$ & 312.46 & & $\begin{array}{l}\text { Benzene, } \\
\text { 5-(1,1-dimethylethyl)-2-[[(2- } \\
\text { ethoxyethyl)sulfonyl]methyl]- } \\
\text { 1,3-dimethyl }\end{array}$ \\
\hline $\begin{array}{c}\text { C6 } \\
\mathrm{C}_{16} \mathrm{H}_{26} \mathrm{O}_{3} \mathrm{~S}\end{array}$ & 298.44 & & $\begin{array}{l}\text { 3-\{[2,6-Dimethyl-4-(2-methyl- } \\
\text { 2-propanyl)benzyl]sulfonyl }\} \text { - } \\
\text { 1-propanol }\end{array}$ \\
\hline $\begin{array}{c}\text { C7 } \\
\mathrm{C}_{12} \mathrm{H}_{26} \mathrm{O}_{4} \mathrm{~S}\end{array}$ & 266.39 & & $\begin{array}{l}\text { 3D } \\
\text { 1-(Ethylsulfonyl)-5-methoxy- } \\
\text { 6,6-dimethyl-4-heptanol }\end{array}$ \\
\hline $\begin{array}{c}\text { C8 } \\
\mathrm{C}_{15} \mathrm{H}_{24} \mathrm{O}_{3} \mathrm{~S}\end{array}$ & 284.14 & & $\begin{array}{l}(2 \mathrm{R})-3-[(\mathrm{S})-\{(1 \mathrm{R})-1-[4-(2- \\
\text { Methyl-2-propanyl)phenyl] } \\
\text { ethyl }\} \text { sulfinyl]-1,2-propanediol }\end{array}$ \\
\hline
\end{tabular}

The third-generation cephalosporin is isomerised to its second-generation isomer, and leads the antibiotic material to be more stable. The authors suggested that chemical degradation of cephalosporin leads to 7ACA and further degradation leads to thiazole-4-carboxylic acid. ${ }^{33}$ The presence of the thiazole-carboxyl group is present in the first intermediate, $\mathrm{C}_{1}$ found, leading to conclude that the hypothesis is valid. 
Further degradation is observed in intermediates following the 5-thizole carboxylic acid with elimination of side methyl groups as it can be seen in the $\mathrm{C}_{2}$ molecule 5-[5-(methoxymethyl)-1,2-oxazol-3-yl]-4H-1,2,4-triazole-3(4-diamine). The role of iron as catalyst acts in such a way that mercaptide group is formed. This is confirmed in the $\mathrm{C}_{1}, \mathrm{C}_{3}$ and $\mathrm{C}_{8}$ intermediate. There is the presence of the sulphur atom rendering the component mercaptide. ${ }^{36}$

It is quite hard to assign the exact location of substitute or leaving functional groups of the complex parent molecule simply by looking at the molecules. The LC/MS analysis is unable to provide such information. A further study on bondforming and bond-breaking has to be made to be more accurate in conclusion. However, Trovo et al. used similar methods to degrade similar forms of antibiotic suggests that, there are approximately three degradation pathways which can be determined. ${ }^{33}$

From the parent molecule, Trovo et al. also suggest that hydroxylation occurs first and results to thiazolidine ring (confirmed by $\mathrm{C}_{1}$ intermediate). Later, the next attack is most probable on electrophilic nature, i.e., benzoic ring as shown in $\mathrm{C}_{6}$, $\mathrm{C}_{5}$ and $\mathrm{C}_{4}$ intermediate. There is opening of the benzoic ring from $\mathrm{C}_{6}$ intermediate to $\mathrm{C}_{7}$ intermediate. While another pathway suggests the side methyl groups can gradually be eliminated as shown from $\mathrm{C}_{5}$ to $\mathrm{C}_{8}$ intermediate. ${ }^{33}$

Another pathway suggested by Trovo et al. is the direct opening of the lactam ring to stereo isomers of penoilloic acid and a series of derivatives $\left(\mathrm{C}_{2}, \mathrm{C}_{4}\right.$ and $\mathrm{C}_{6}$ ). Further decarboxylation is the removal of carboxylic functional group. This is shown through the intermediates $\mathrm{C}_{2}, \mathrm{C}_{3}$ and $\mathrm{C}_{7}$. Decarboxylation is produced by hydrolysis. ${ }^{30}$

\section{CONCLUSION}

The antibiotic ceftriaxone has been successfully degraded by $84.6 \%$ within 30 min of degradation. The total suspended solids level was reduced by $93 \%$ after the Fenton treatment. It can be concluded that parameters such as $\mathrm{pH}$ and temperature affected the degradation process. The optimum operating conditions at ambient temperature are reflected at $\mathrm{pH} 2.6$, Fenton reagent concentration of $0.4 \mathrm{M}$ and $\mathrm{Fe}^{2+} / \mathrm{H}_{2} \mathrm{O}_{2}$ molar ratio of 1:8. From the identified degradation products, ceftriaxone complex $\mathrm{C}_{18}$-molecular structure has been reduced till $\mathrm{C}_{3}$-molecular structure. Further treatment includes neutralisation of treated sample by use of sodium hydroxide and application of carbon capture methods to reduce the emission of carbon dioxide gas. 


\section{ACKNOWLEDGEMENTS}

This work was funded by School of Engineering, Taylor's University, Malaysia. The authors gratefully acknowledged School of Engineering for permission to carry out this work as a final year project.

\section{REFERENCES}

1. Kummerer, K. (2003). Significance of antibiotics in the environment. J. Antimicrob. Chemother, 52, 5-7, https://doi.org/10.1093/jac/dkg293.

2. Hollis, A. \& Ahmed, Z. (2013). Preserving antibiotics, rationally. N. Engl. J. Med., 369, 2474-2476, https://doi.org/10.1056/NEJMp1311479.

3. Bailón-Pérez, M. et al. (2008). Trace determination of $\beta$-lactam antibiotics in environmental aqueous samples using off-line and on-line preconcentration in capillary electrophoresis. J. Chromatogr. A, 1185, 273-280, https://doi. org/10.1016/j.chroma.2007.12.088.

4. Tuc Dinh, Q. et al. (2011). Measurement of trace levels of antibiotics in river water using on-line enrichment and triple-quadrupole LC-MS/MS. Talanta, 85, 1238-1245, https://doi.org/10.1016/j.talanta.2011.05.013.

5. Al Aukidy, M. et al. (2012). Monitoring release of pharmaceutical compounds: Occurrence and environmental risk assessment of two WWTP effluents and their receiving bodies in the Po Valley, Italy. Sci. Total Environ., 438, 15-25, https://doi.org/10.1016/j.scitotenv.2012.08.061.

6. Cha, J. M., Yang, S. \& Carlson, K. H. (2006). Trace determination of $\beta$-lactam antibiotics in surface water and urban wastewater using liquid chromatography combined with electrospray tandem mass spectrometry. $J$. Chromatogr. A, 1115, 46-57, https://doi.org/10.1016/j.chroma.2006.02.086.

7. Wang, C. et al. (2011). Investigation of pharmaceuticals in Missouri natural and drinking water using high performance liquid chromatography-tandem mass spectrometry. Water Res., 45, 1818-1828, https://doi.org/10.1016/j. watres.2010.11.043.

8. Watkinson, A. et al. (2009). The occurrence of antibiotics in an urban watershed: From wastewater to drinking water. Sci. Total Environ., 407, 2711-2723, https://doi.org/10.1016/j.scitotenv.2008.11.059.

9. Zou, S. et al. (2011). Occurrence and distribution of antibiotics in coastal water of the Bohai Bay, China: Impacts of river discharge and aquaculture activities. Environ. Pollut., 159, 2913-2920, https://doi.org/10.1016/j. envpol.2011.04.037. 
10. Shimizu, A. et al. (2013). Ubiquitous occurrence of sulfonamides in tropical Asian waters. Sci. Total Environ. 452-453, 108-115, https://doi. org/10.1016/j.scitotenv.2013.02.027.

11. Kümmerer, K. (2009). Antibiotics in the aquatic environment - A review - Part I. Chemosph., 75, 417-434, https://doi.org/10.1016/j. chemosphere.2008.11.086.

12. Demotes-Mainard, F. M. et al. (1988). Micromethod for determination of ceftriaxone in plasma and urine by high-performance liquid chromatography. J. Pharm. Biomed. Anal., 6, 407-413, https://doi.org/10.1016/07317085(88)80006-2.

13. Ayandiran, T. A. et al. (2014). Microbial assessment and prevalence of antibiotic resistance in polluted Oluwa River, Nigeria. Egypt. J. Aquat. Res., 40, 291-299, https://doi.org/10.1016/j.ejar.2014.09.002.

14. Halling-Sørensen, B. et al. (1988). Occurrence, fate and effects of pharmaceutical substances in the environment - A review. Chemosph., 36, 357-393, https://doi.org/10.1016/S0045-6535(97)00354-8.

15. Zwiener, C. (2000). Oxidative treatment of pharmaceuticals in water. Water Res., 34, 1881-1885, https://doi.org/10.1016/S0043-1354(99)00338-3.

16. Ternes, T. A. et al. (2002). Removal of Pharmaceuticals during drinking water treatment. Environ. Sci. Technol., 17, 36AD, https://doi.org/10.1021/ es $015757 \mathrm{k}$.

17. Hartig, C., Ernst, M. \& Jekel, M. (2001). Membrane filtration of two sulphonamides in tertiary effluents and subsequent adsorption on activated carbon. Water Res., 16, 3998-4003, https://doi.org/10.1016/S00431354(01)00109-9.

18. Petrovic, M. (2003). Analysis and removal of emerging contaminants in wastewater and drinking water. Trends Anal. Chem., 22, 685-696, https:// doi.org/10.1016/S0165-9936(03)01105-1.

19. Nithyanandam, R. \& Saravanane, R. (2013). Treatment of pharmaceutical sludge by fenton oxidation process. Int. J. Chem. Eng. Appl., 4, 360-364, https://doi.org/10.7763/ijcea.2013.v4.325.

20. Mansour, D. et al. (2015). Mineralization of synthetic and industrial pharmaceutical effluent containing trimethoprim by combining electroFenton and activated sludge treatment. J. Taiwan Inst. Chem. Eng., 53, 5867, https://doi.org/10.1016/j.jtice.2015.02.022.

21. Arslan-Alaton, I. \& Gurses, F. (2004). Photo-Fenton-like and photofenton-like oxidation of Procaine Penicillin $G$ formulation effluent. J. Photochem. Photobiol. A Chem., 165, 165-175, https://doi.org/10.1016/j. jphotochem.2004.03.016. 
22. Biedenbach, D. J., Iaconis, J. P. \& Sahm, D. F. (2016). Comparative in vitro activities of ceftaroline and ceftriaxone against bacterial pathogens associated with respiratory tract infections: results from the AWARE surveillance study. J. Antimicrob. Chemother, 71, 3459-3464, https://doi. org/10.1093/jac/dkw315.

23. Ab Rahman, N., Teng, C. L. \& Sivasampu, S. (2016). Antibiotic prescribing in public and private practice: a cross-sectional study in primary care clinics in Malaysia. BMC Infect. Dis., 16, 208, https://doi.org/10.1186/s12879-0161530-2.

24. Sulong, A. M. et al. (2015). IV ceftriaxone use in Tuanku Mizan Armed Forces Hospital. Malaysian J. Pharm., 2, 165.

25. Quand-Meme, G. et al. (2016). Electrooxidation of ceftriaxone in its commercial formulation on boron doped diamond anode. Adv. Electrochem., 2, 85-88.

26. American Public Health Association, American Water Works Association, Water Environment Federation. (1999). Standard methods for the examination of water and wastewater, USA.

27. American Water Works Association (1999). Total suspended solids standard method 2540 D: Standard methods for the examination of water and wastewater. New York: American Public Health Association.

28. Royal Society of Chemistry. (2016). Chemspider. Retrieved on 5 January 2015 from http://www.chemspider.com.

29. Metcalf \& Eddy. (2003). Wastewater engineering: Treatment and reuse. New York: McGraw-Hill.

30. Moon, D. et al. (1991). Chemical oxidation of polyaniline by radical generating reagents, $\mathrm{O}_{2}, \mathrm{H}_{2} \mathrm{O}_{2}-\mathrm{FeCl}_{3}$ catalyst, and dibenzoyl peroxide. Chinese Chem. Lett., 9, 1633-1636, https://doi.org/10.1246/cl.1991.1633.

31. Giri, A. \& Golder, A. (2014). Ciprofloxacin degradation from aqueous solution by Fenton oxidation: Reaction kinetics and degradation mechanisms. RSC Adv., 4, 6738, https://doi.org/10.1039/c3ra45709e.

32. Zanta, C. \& Martínez-Huitle, C. (2009). Degradation of 2-hydroxybenzoic acid by advanced oxidation processes. Brazilian J. Chem. Eng., 26, 503513, https://doi.org/10.1590/S0104-66322009000300006.

33. Trovó, A. et al. (2011). Degradation of the antibiotic amoxicillin by photoFenton process - Chemical and toxicological assessment. Water Res., 45, 1394-1402, https://doi.org/10.1016/j.watres.2010.10.029.

34. Pignatello, J. J., Oliveros, E. \& Mackay, A. (2006). Advanced oxidation processes for organic contaminant destruction based on the fenton reaction and related chemistry. Crit. Rev. Environ. Sci. Technol., 36, 1-84, https://doi. org/10.1080/10643380500326564. 
35. Su, M. et al. (2016). Degradation kinetics and mechanism of a $\beta$-lactam antibiotic intermediate, 6-aminopenicillanic acid, in a new integrated production process. J. Pharm. Sci., 105, 139-146, https://doi.org/10.1016/j. xphs.2015.11.026.

36. Deshpande, A., Baheti, K. \& Chatterjee, N. (2004). Degradation of betalactam antibiotics. Curr. Sci., 87, 1684-1695. 